\title{
電気・空気圧複合駆動システムとその制御法に関する研究*
}

\author{
中田毅**, 桜井康 雄***, 田中和 博****
}

\section{A Study of an Electric-Pneumatic Hybrid Drive System and its Control Methods}

\author{
Takeshi NAKADA, Yasuo SAKURAI, Kazuhiro TANAKA
}

\begin{abstract}
This paper deals with the proposal of an electric-pneumatic hybrid drive system composed of an AC servomotor and a pneumatic cylinder type actuator, and its control methods. The rotational movement of the AC servomotor is transformed into the linear movement through a ball screw that is placed in the piston, and this hybrid drive system can be operated in the direction of gravitational force. Three control methods such as a pressure compensated control, a torque control and a hybrid control that combines both control methods are proposed from the view point of the reduction of the driving torque of the AC servomotor. The basic characteristics of the hybrid drive system are investigated by the experiment relating to the three control methods when the inertial mass moves vertically upwards and downwards during one cycle. Each control method is effective in reducing the driving torque of the AC servomotor and the views on the reduction of the driving torque of the AC servomotor in each control method are described.
\end{abstract}

Key Words : Actuator, Pressure control, Torque control, Feedback control, Control method, Electro-pneumatic hybrid drive system, Hybrid control

\section{1. 緒 言}

電気アクチュエータは応答性が高く，高精度な制御が容 易であり, また空気圧アクチュエータは安価で, 出力重量 比が大きく, 高速駆動が可能であるなどの利点があり, 一 般産業分野や科学技術分野における様々な駆動システムの アクチュエータとしてそれぞれ広く利用されている. しか し, 電気アクチュエータは保持力が小さく, 高出力を求め ると重量が大きくなりがちであり, 垂直方向駆動システム に用いると負荷を保持するためには多くの電力を消費す

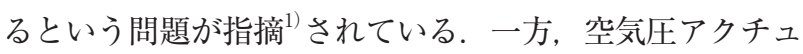
エータは空気の圧縮性により高精度制御が難しいなどの久 点がある. 近年, 省エネルギーで小形・高性能な駆動シス テムの実現が強く求められており, その実現に向けて電気 アクチュエータと空気圧アクチュエータの利点を生かし, それぞれの欠点を補完する電気・空気圧複合駆動システム の研究・開発が進められている.

* 平成19年 6 月 4 日 原稿受付

** 東京電機大学情報環境学部情報環境学科

(所在地 ₹270-1382 千葉県印西市武西学園台2-1200)

(E-mail: nakada@sie.dendai.ac.jp)

*** 足利工業大学工学部機械工学科

(所在地 \%326-8558 栃木県足利市大前町268-1)

(E-mail: ysakurai@ashitech.ac.jp)

****九州工業大学情報工学部機械情報工学科

(所在地 $\overline{7} 820-8502$ 福岡県飯塚市川津680-4)

(E-mail: kazuhiro@vortex.mse.kyutech.ac.jp)
伊藤 ${ }^{2)}$ は, 空気圧シリンダのピストンをボールねじ駆動 する電動方式の垂直駆動装置の概念を提示し, それに基 づき具体的提案と試作を行っている. 武村ら ${ }^{3)}$ は, 空気圧 モータと電動モータを組み合わせたハイブリッドモータを 提案し, 出力重量比と停止位置精度の観点から, その設計 法と制御方法を論じている. 田中ら ${ }^{4)}$ は, 直動型空気圧ア クチユエータとワイヤ・プーリにより直線運動が可能な変 換機構を備えた電動モー夕から構成される垂直方向直線駆 動型アクチュエータの試作と周波数応答実験による性能評 価を行っている.

このような背景の下本研究では, 空気圧シリンダと, ピ ストン内に設置されたボールねじにより直線運動が可能な 変換機構を備えた同期型 ACサーボモー夕(以下, ACモー 夕）を組み合わせた垂直方向の直線駆動型電気・空気圧複 合駆動システム（以下, 複合駆動システム) を提案・試作 し， ACモータのトルクを低減して AC モータの小型化を 図るという観点から, 当該複合駆動システムの制御法とし て圧力補償制御, トルク制御およびそれらを併用した複合 制御を提案し, 実験により各制御法の有効性と特長を明ら かにする.

\section{主な記号}

$k_{p}:$ 圧力 - 電-空レギュレータ入力電圧換算係数

$k_{\tau}:$ : トク -電-空レギュレータ入力電圧換算係数

$P_{h}(t)$ : 保持圧力

$t \quad:$ 時間

$t_{u} \quad$ : 負荷質量加算時刻 


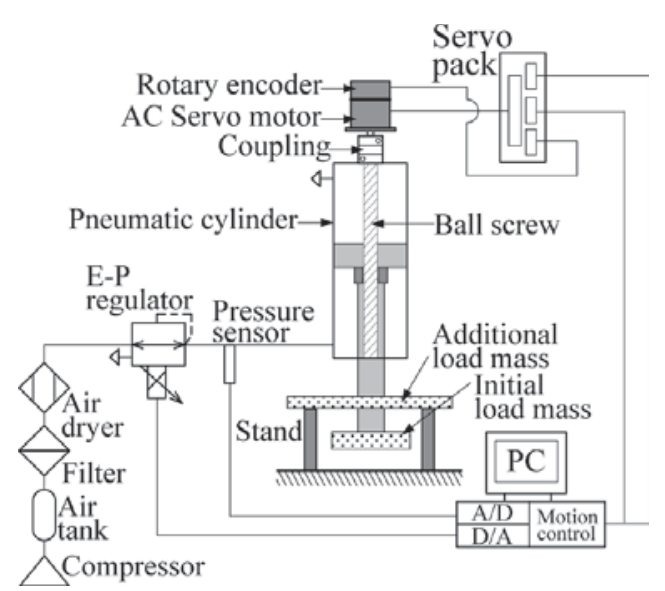

Fig. 1 Electric-pneumatic hybrid drive system

$t_{d} \quad$ : 負荷質量除去時刻

$V_{p} \quad$ : 保持圧力による電一空レギュレータ入力電圧

$V \tau$ : トルク制御系による電一空レギュレータ入力電圧

$\tau_{A C}(t): \mathrm{AC}$ モータの出力トルク

$\tau_{C}(t)$ : トルク制御系の目標值

\section{2. 複合駆動システムの構成と実験装置}

提案・試作した複合駆動システムは速度指令同期型 $\mathrm{AC}$ モー夕駆動系と空気圧駆動系を複合化した駆動システムで あり，工業的によく使用される垂直方向（重力方向）に負 荷質量を駆動するシステムを対象としている. 図 1 に試作 した実験装置の概略を示すＡ AC モー夕駆動系は速度ルー プゲイン, 速度ループ積分時定数㧍よび位置ループゲイン を指定できるフィードバック制御系で構成されており，専 用のサーボパックによって駆動制御が行われる. AC モー 夕の回転数はロータリーエンコーダにより，またトルク

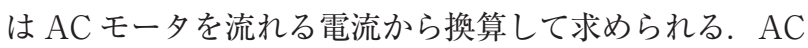
モータの回転運動はピストン内に設置されたボールねじに より直線運動に変換される. 空気圧駆動系は片ロッドシ リンダを用い，ロッド側に設置された電-空レギュレータ によってロッド側圧力が制御される。また，シリンダヘッ ド側は常に大気圧に開放されている. 従って, 複合駆動シ ステムは AC モー夕駆動系および空気圧駆動系によって, それぞれ単独あるいは両者を協調的に複合して駆動できる ようになっている. 両駆動系の主な仕様は以下のと扔りで ある。

(1) AC モー夕駆動系

- 定格電力

$100(\mathrm{~W})$

・定格トルク

$0.32(\mathrm{Nm})$

・瞬時最大トルク

$0.96(\mathrm{Nm})$

- 定格回転速度

$3000(\mathrm{rpm})$

(2)空気圧駆動系

・供給圧力

$0.5(\mathrm{MPa})$

・シリンダ内径

$63(\mathrm{~mm})$

・ピストンロッド径

$25(\mathrm{~mm})$

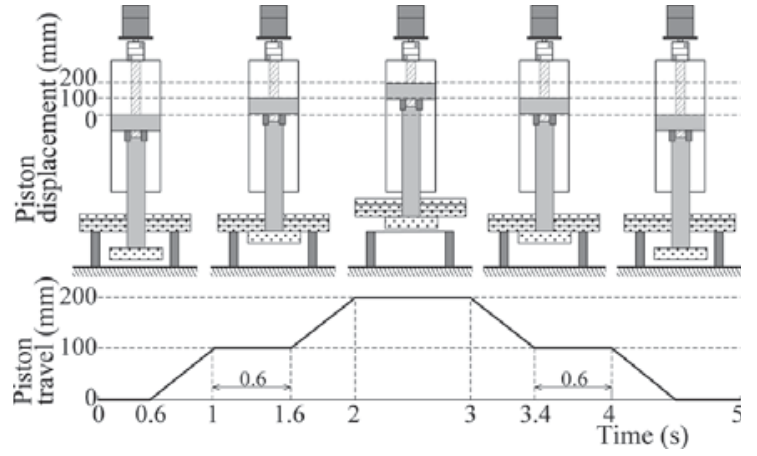

Fig. 2 Basic piston travel

-ピストン最大ストローク $400(\mathrm{~mm})$

・ボールねじリード $10(\mathrm{~mm})$

本研究で用いた基本的なピストン行程は図 2 のようであ る. 初期負荷質量はピストン自体の質量を含めて $14.2 \mathrm{~kg}$ で あり，ピストン上昇行程においては初期位置から $100 \mathrm{~mm}$ 昇した位置で一旦停止し，つぎに $30 \mathrm{~kg} の$ 負荷質量が加算 されて，さらに $100 \mathrm{~mm}$ 上昇した位置で停止する。 下降行程 においてはこの停止位置から $100 \mathrm{~mm}$ 下降した位置で一旦停 止し，つぎに上昇行程で加算された $30 \mathrm{~kg}$ の負荷質量が除 去され, 初期負荷質量のみとなってさらに $100 \mathrm{~mm}$ 下降し, もとの初期位置で停止する. シリンダのロッド側には，図 1 中の電-空レギュレータを用いて初期負荷質量の重力と ピストン・シリンダ間の静止摩擦力に鈞り合うような圧力 （保持圧力：0.05MPa）を予め与えている. また，以下の 実験における AC モー夕の設定回転速度は 1500rpm であ り，250mm/s のピストン速度に相当する。

\section{3. 複合駆動システムの制御駆動実験}

$\mathrm{AC}$ モータのトルクを低減して AC モータの小型化を図 るという観点から，はじめに当該システムの基本的な制御 特性を把握するため AC モー夕駆動系単体の基本的な制御 駆動実験を行った，その実験結果に基づき，あらか心゙め既 知である負荷質量変動による重力変動を補償するためロッ ド側圧力を制御する圧力補償制御駆動実験，負荷質量変動 が未知の場合について, 駆動時の AC モー夕の発生する トルクをゼロにするようにロッド側圧力を制御するトルク 制御駆動実験および，それら両者を複合化した複合制御駆 動実験を行った結果について述べる5 ${ }^{5}$. これらの制御系の 擬似的なブロック線図を図 3 に示す. 図中の破線部は後述 のトルク制御部を示す。

\subsection{ACモータ駆動系単体制御駆動実験}

複合駆動システムの基本的な制御特性を把握するため, 図 3 のブロック線図中の破線で示したトルク制御部を除去 し, 前述した初期負荷質量を保持する保持圧力指令を与 えて電-空レギュレータによりロッド側圧力（保持圧力： $0.05 \mathrm{MPa}$ ）をほぼ一定に保ち, 図2で示したピストン行程 で駆動制御実験を行った。このときのブロック線図を図 4 


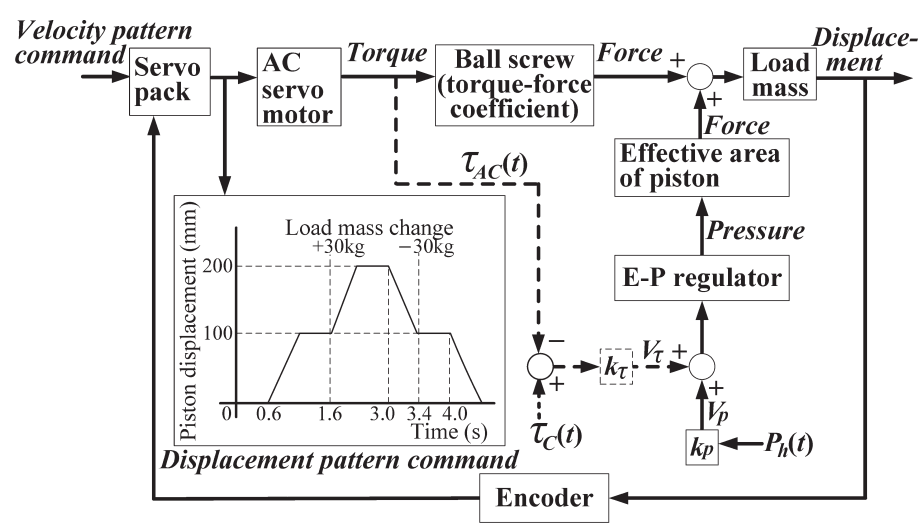

Fig. 3 Pseudo block diagram of electric-pneumatic hybrid drive system

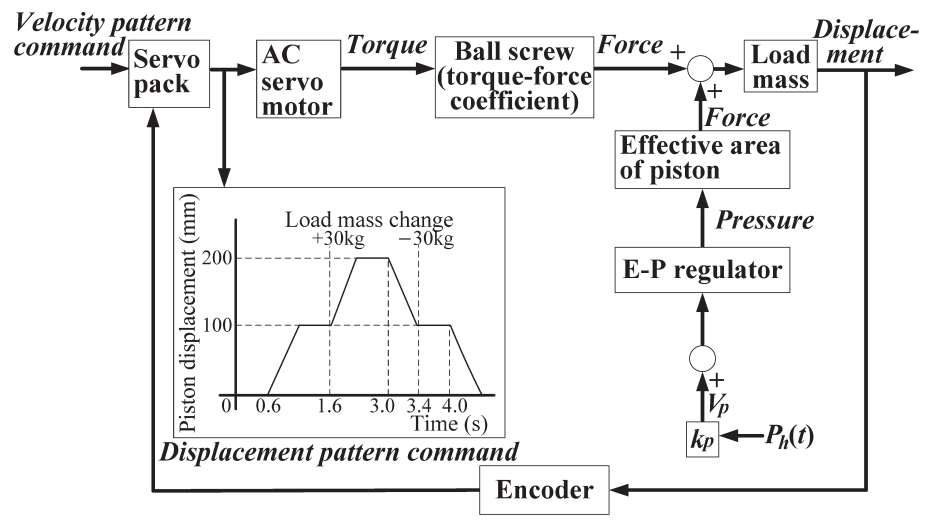

Fig. 4 Pseudo block diagram of electric-pneumatic hybrid drive system (without torque control loop)

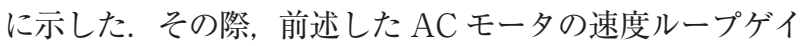
ン，速度ループ積分時定数および位置ループゲインは初期 負荷質量の状態で駆動したときのピストン変位において, (1)制御精度が良い，(2)整定時間が速い，(3)オーバーシュー トが発生しない，などの条件を考慮して設定し，以後の実 験ではこれらの設定值を用いている。ACモー夕駆動系単 体制御駆動実験におけるピストン変位，AC モータのトル クおよびシリンダロッド側圧力の結果を図 5 に示す。AC モータのトルク応答に注目すると, ピストン始動時と停止 時においては負荷質量の加減速にともなう慣性力のため瞬 間的に大きなトルクが発生しており，また $30 \mathrm{~kg}$ の負荷質 量が加算された状態では AC モータのトルクは瞬時最大 トルク $(0.96 \mathrm{Nm})$ に達し，規定時間（10 秒）以上にこの 停止状態を維持することは困難であった。ロッド側シリン ダ圧力はピストンの始動および停止時に幾分圧力変動が発 生しているが，全体的にはほぼ一定圧力を保持している. また，ピストン上昇行程におけるピストン変位には 4 章で 述べるように負荷質量変動の影響が認められ，安定した駆 動を行うためにはより大きな定格トルクの AC モータが 必要となる。

\section{2 圧力補償制御駆動実験}

図 3 のブロック線図において破線で示したトルク制御部 を除去し，図 2 で示したピストン行程において，加算ある いは除去される変動負荷質量 $(30 \mathrm{~kg})$ による重力をシリ

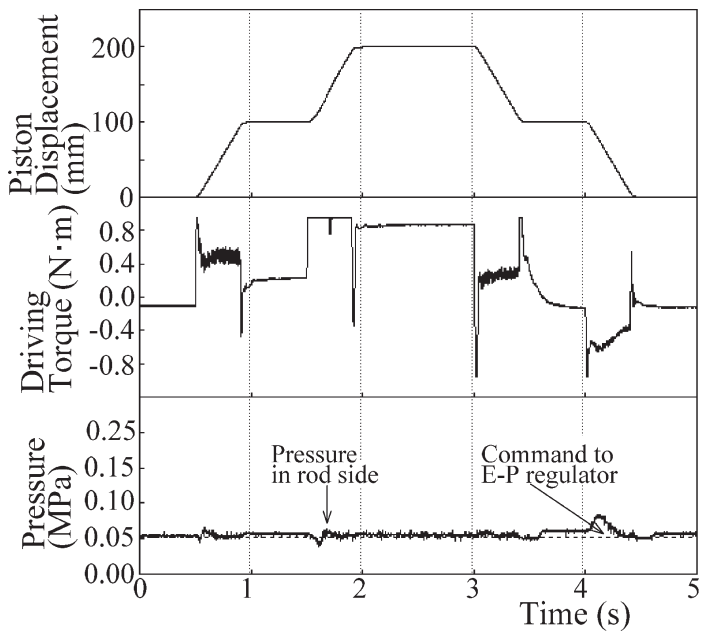

Fig. 5 Time responses of piston displacement, driving torque and pressure in rod side (AC servomotor drive)

ンダロッド側圧力で相殺・補償するように, すなわち, 負 荷質量加算時にはシリンダロッド側圧力を $0.17 \mathrm{MPa}$ 高め, 負荷質量除去時にはこの高めた圧力を初期状態の保持圧力 （0.05MPa）まで減圧するように電-空レギュレータへの保 持圧力指令を制御すれば, AC モータのトルクの増加を抑 制することが可能であると考えられる。しかし，電-空レ ギュレータの給気および排気特性はそれぞれ異なる時間遅 れを有しているので，予め実験的に求めた各時間遅れを考 


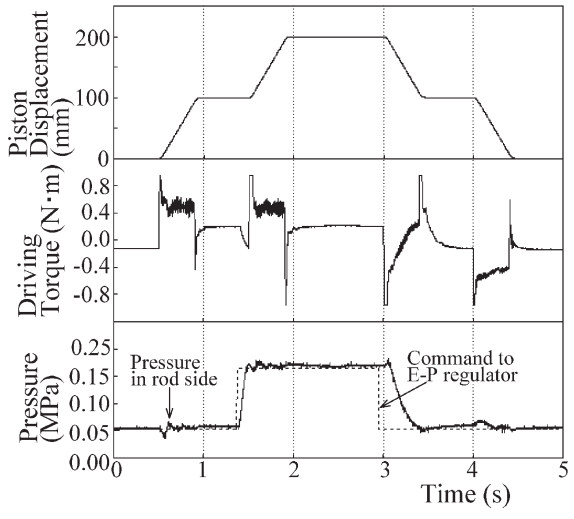

Fig. 6 Time responses of piston displacement, driving torque and pressure in rod side (hybrid drive in pressure compensation control)

慮し,ピストン上昇行程においては負荷質量加算時の $0.13 \mathrm{~s}$ 前に, また下降行程においては負荷質量除去時の $0.45 \mathrm{~s}$ 前 に前述した保持圧力指令を与えた。 このときのブロック 線図は 3.1 の AC モー夕駆動系単体制御駆動実験で述べた ブロック線図（図 4参照）と同様であるが, AC モー夕駆 動系単体制御駆動実験では保持圧力が一定で, $P_{h}(t)=0.05$ $(\mathrm{MPa})$ であるのに対し, 圧力補償制御では以下のように 変動負荷質量に応じて保持圧力 $P_{h}(t)$ を調整している点が 異なる。

$$
\begin{aligned}
0 \leqq & t<t_{u}-0.13 \quad P_{h}(t)=0.05(\mathrm{MPa}) \\
& \text { 従って, } \quad V_{p}=0.05 k_{p} \\
t_{u}-0.13 \leqq t<t_{d}-0.45 \quad P_{h}(t)=0.22(\mathrm{MPa}) & \\
& \text { 従って, } \quad V_{p}=0.22 k_{p} \\
t \geqq & t_{d}-0.45 \quad P_{h}(t)=0.05(\mathrm{MPa}) \\
& \text { 従って, } \quad V_{p}=0.05 k_{p}
\end{aligned}
$$

その実験結果を図 6 に示すが, 前述の AC モー夕駆動系 単体制御駆動の場合に比較して全体的に AC モータのト ルクは大幅に低減され，また良好なピストン行程が実現さ れており，大きな制御効果が認められた。 しかし，ピス卜 ン始動時および停止時には短時間ではあるが瞬時最大卜ル クに達しており，またピストン移動時および停止状態にお いても $0.4 \sim 0.2 \mathrm{Nm}$ 程度のトルクが発生している.これは, 負荷質量の慣性力, 動摩擦力の影響を考慮していないこと, および図 6 中のシリンダロッド側圧力応答からわかるよう に電-空レギュレータとシリンダ系の正確な動特性の補償 が行われていないことによるものと考えられる．本圧力補 償制御法は, 図 2 に示したように負荷質量変動の大きさと 変動時刻が予め既知の場合には有効な制御法であり, 負荷 変動の大きさについておおよその大きさが既知であれば制 御性能の良好な $\mathrm{AC}$ モータでその誤差分は制御可能であ るが，負荷変動時の急激なトルクの上昇の抑制とピストン 移動時および停止状態におけるトルクの低減には，正確な 変動時刻が予め既知であることおよび上述の慣性力，動摩 擦力および電-空レギュレータとシリンダ系の動特性の影

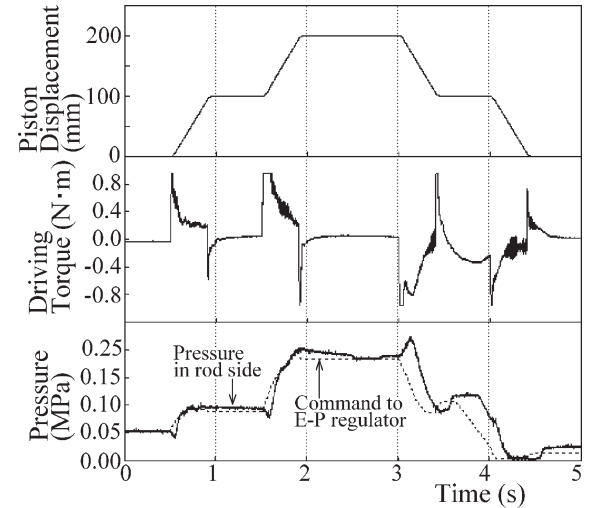

Fig. 7 Time responses of piston displacement, driving torque and pressure in rod side (hybrid drive in torque control)

響に対する正確な考慮が必要である。

\section{3 トルク制御駆動実験}

3.2 で述べた圧力補償制御では，基本的には予め負荷質 量変動の大きさと変動時刻が既知であることが要求され る。そこで，これらが未知の場合に対応するため図 3 中の 破線部で示すように，ACモータのトルクを検出し，その トルクが $\tau_{C} \mathrm{Nm}$ (目標值) となるようにシリンダロッド側 圧力を電-空レギュレータで制御する内部フィードバック 制御を検討した. 具体的な制御方式は以下のとおりである.

$$
V_{\tau}=k_{\tau}\left(\tau_{c}-\tau_{A C}\right)
$$

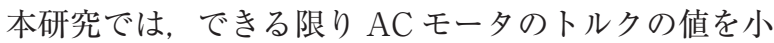
さくするため, $\tau_{c}=0$ とした

従って, $V_{\tau}=-k_{\tau} \cdot \tau_{A C}$

その実験結果を図 7 に示すが，全体的には前述の圧力補 償制御の場合と同様な制御効果が認められた。 AC モー夕 の停止状態時に注目すると, そのトルクはほぼ $0 \mathrm{Nm}$ であ り, 圧力補償制御の場合より良好な制御特性を示す一方, 負荷質量加算・除去時に注目するとトルクが瞬時最大卜 ルクとなる時間が増大する欠点が認められた。これは $\mathrm{AC}$ モータのトルクを検出して制御が行われるフィードバック 制御を採用していることに起因する.

\section{4 複合制御駆動実験}

3.2 および 3.3 で述べたように, 圧力補償制御およびト ルク制御にはそれぞれ長所・短所が認められたが，両者の 欠点を補完するため圧力補償制御とトルク制御を同時に併 用した複合制御を検討した，具体的には，式(1)〜式(3)拉よ び式(5)を用いて圧力補償制御及びトルク制御に㧍ける電一 空レギュレータへの入力電圧を求め, それらを加え合わせ た電圧を電－空レギュレータへの入力信号とした，すなわ ち,

$$
V=V_{p}+V_{\tau}
$$

その実験結果を図 8 に示すが，圧力補償制御とトルク制 御に比べて以下のような効果が認められた。

(a)圧力補償制御駆動実験結果（図 6) のピストン上昇行 


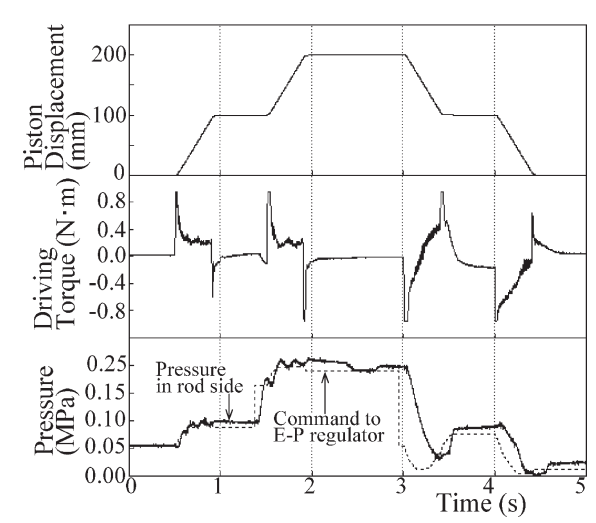

Fig. 8 Time responses of piston displacement, driving torque and pressure in rod side (hybrid drive in hybrid control)

程 $(0 \mathrm{~s} \sim 3 \mathrm{~s})$ におけるピストン上昇時および停止時の定 常駆動トルクに注目すると, 複合駆動制御ではいずれも約 $0.2 \mathrm{Nm}$ の駆動トルクの低減が認められる.

(b)トルク制御駆動実験結果（図 7）において, 負荷質量 加算後のピストン上昇直後 (約 $1.5 \mathrm{~s}$ 直後) の最大トルク の持続時間に注目すると, トルク制御では約 $0.12 \mathrm{~s}$ である のに対し複合制御では約 $0.04 \mathrm{~s}$ であり, 持続時間が約 $1 / 3$ に短縮されている.

\section{4. 負荷質量衝突実験}

これまでは図 2 で示したように, 負荷質量加算・除去時 に $0.6 \mathrm{~s}$ 間ピストンを一旦停止させたが, 図 9 に示すよう にピストンを停止せず, 加算される負荷質量と初期負荷質 量を衝突および分離させて駆動することにより複合駆動シ ステムのサイクルタイムを短縮することが実用上要求され ることも多い. そこで, 眓 9 のピストン行程に関し, これ までと同様の制御駆動実験を行った。これまでの実験結果 から明らかなように, 負荷質量変動が AC モータのトル クに与える影響はピストン下降行程よりもピストン上昇行 程のほうが著しいので, ピストン上昇行程におけるピスト

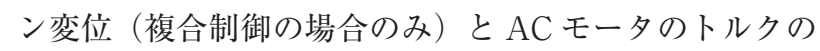

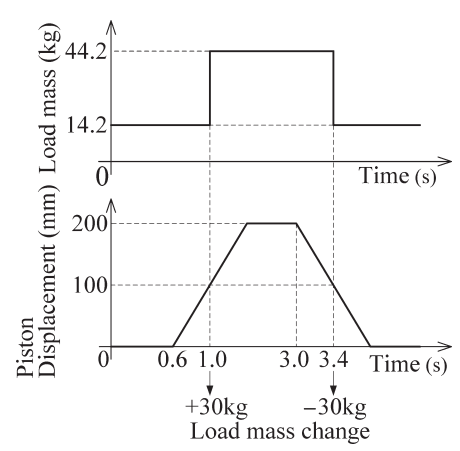

Fig. 9 Piston travel under mutual load mass collision

実験結果を図 10 に示した，衝突して負荷質量が加算され た以降のトルクに注目すると, 負荷衝突時 (1.0s) 近傍で はいずれの制御法でも負荷質量および負荷質量の加速トル クの増大により瞬時最大トルクに達しているが, 圧力補償 制御および複合制御における瞬時最大トルク持続時間はト ルク制御のそれに比べて半隇している。 また，瞬時最大卜 ルク持続時間以降はいずれの制御法でも急速にトルクが減 少しているが, 特に複合制御でその傾向が著しく, ほぼ定 格トルク以下で整定しており, 最もトルクの軽減に有効で あると考えられる. 図 11 はこのときのピストン上昇行程 におけるピストン変位の時間経過を示したものであるが, 負荷衝突時以降の AC モータ駆動系単体制御駆動のピス トン変位は指定されたピストン行程 (図 9 参照) から大き くずれている. 一方, 提案した 3 種類の制御法ではいずれ も衝突直後やや振動的であるが, ほぼ良好な変位応答を示 している.

\section{1 行程平均トルクの比較}

図 2 および図 9 に示したピストンの 1 行程について, 各 制御法における AC モー夕の 1 行程あたりの平均トルク $\tau_{a v}$ を求め, 比較した. この平均トルクは 1 行程の始まる 時刻を $T_{s}$, 終了時刻を $T_{e}$, 前述の各実験で得られたこの間 のトルクを $\tau(t)$ として, 以下のように求めた.

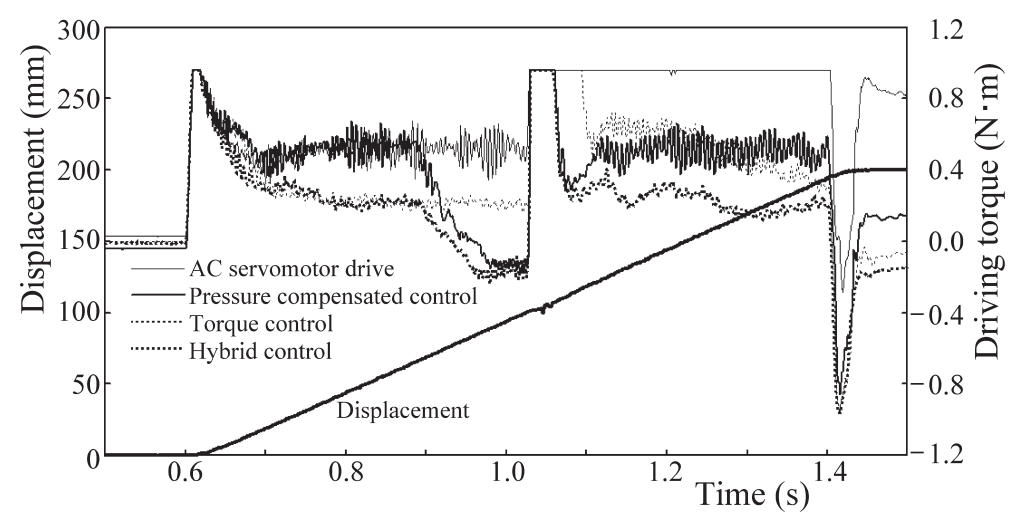

Fig. 10 Time responses of piston displacement, driving torque and pressure in rod side (hybrid drive in climbing piston travel under mutual load mass collision) 


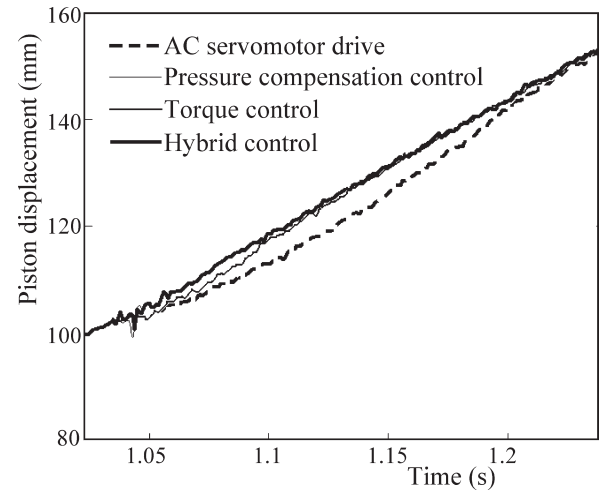

Fig. 11 Responses of climbing piston displacement under mutual load mass collision

$$
J_{1}(C)=\frac{\partial \mathrm{h}(C)}{\partial C}
$$

その結果を図 12 に示す。この図で黒棒および斜線棒は それぞれ図 2 および図 9 で示したピストン行程の場合の結 果を示している。いずれの制御法においても AC モー夕駆 動系単体制御駆動における時間平均トルクの $50 \%$ 以下で, 特に複合制御では 30\%程度に軽減されており，AC モータ の小型化に極めて有効であることが明らかにされた.

\section{6. 結 言}

AC モータと空気圧アクチュエータを組み合わせた垂直 方向の直線駆動型電気・空気圧複合駆動システムを提案・ 試作した。 また，ACモータのトルクを低減して AC モー 夕の小型化を図るという観点から圧力補償制御，トルク制 御およびそれらを併用した複合制御を提案し, 各制御法と も良好な変位応答を示すとともに, AC モータのトルクの 軽減に有効であることを実験的に明らかにした，ACモー タのトルクの軽減に対する主要な成果は以下のとおりであ る.

(1)負荷質量変動の大きさと変動時刻が既知の場合を対象 とした圧力補償制御は, 負荷変動時に発生するトルクの低 減に大きな効果が認められた.

(2)負荷質量変動の大きさと変動時刻が未知の場合を対象

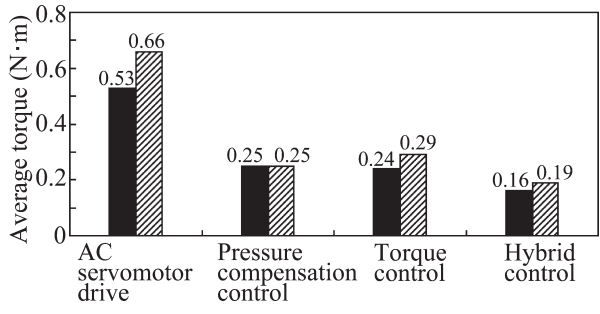

Fig. 12 Comparison of average torque of $\mathrm{AC}$ servomotor

としたトルク制御は，ピストン移動時および停止状態にお けるトルクの低減には有効であるが, 負荷変動直後に発生 するトルクの低減効果は期待できない.

(3)圧力補償制御とトルク制御を併用した複合制御は負荷 変動時に発生するトルクの低減およびピストン移動・停止 状態のトルクの低減の両者に有効である.

本研究を実施するに当たり, SMC 株式会社より種々ご 支援を賜ったことを記し，謝意を表する。

\section{参 考 文 献}

1 ）藤田壽憲, 蔡茂林, 香川利春 : 空気圧シリンダの消費 エネルギーと電動アクチュエータとの比較, 日本フ ルードパワーシステム学会誌，34-2, 49/53 (2003)

2 ) 伊藤勝治郎 : 空気の圧縮性に対する空圧駆動器のアプ ローチ, 日本油空圧学会ウインターセミナー「空気圧 の新たな可能性を求めて」, 29/33（1994）

3 ) 武村史朗, S.R.PANDIAN, 早川恭弘, 川村貞夫 : 八 イブリッド型空気圧・電気駆動モータの設計と制御, 日本機械学会論文集 (C 編)，68-665，117124（2002）

4 ）田中豊, 久隼人, 橋本玲子 : 空気圧電動ハイブリッド アクチュエータに関する研究, 平成 18 年春季フルー ドパワーシステム講演会講演論文集，94/96（2006）

5 ) 田中翔, 中田毅, 桜井康雄, 田中和博 : 電気 - 空気圧 複合駆動システムにおける負荷変動制御方式に関す る研究, 平成 18 年秋季フルードパワーシステム講演 会講演論文集，106/108（2006） 